\title{
Bioinspired, multidisciplinary, iterative catalyst design creates the highest performance peroxidase mimics and the field of Sustainable Ultradilute Oxidation Catalysis (SUDOC)
}

Genoa R. Warner, ${ }^{\dagger}$ Yogesh Somasundar ${ }^{\dagger}$ Kyle C. Jansen, ${ }^{\dagger}$ Evan Z. Kaaret, ${ }^{\dagger}$ Cindy Weng, ${ }^{\dagger}$ Abigail E. Burton, ${ }^{\dagger}$ Matthew R. Mills, ${ }^{\dagger}$ Longzhu Q. Shen, ${ }^{\dagger}$ Alexander D. Ryabov ${ }^{\dagger *}$ Gabrielle Pros, ${ }^{\star}$ Tomislav Pintauer, ${ }^{\star *}$ Saborni Biswas, ${ }^{\dagger}$ Michael P. Hendrich, ${ }^{\dagger *}$ Julia A. Taylor, ${ }^{\mathbb{T}}$ Frederick S. Vom Saal, ${ }^{\mathbb{T} *}$ and Terrence J. Collins ${ }^{\dagger *}$

\section{3, United States}

$\neq$ Department of Chemistry and Biochemistry, 600 Forbes Ave, Duquesne University, Pittsburgh, Pennsylvania, 15282, United States gDivision of Biological Sciences, University of Missouri, MO 65211, United States

¥University of Cambridge, Downing Street, Cambridge CB2 3EJ, United Kingdom

Corresponding Authors

*tc1u@andrew.cmu.edu

*ryabov@andrew.cmu.edu

* pintauer@duq.edu

* hendrich@andrew.cmu.edu

*VomsaalF@missouri.edu 


\section{SUPPLEMENTARY FIGURES}

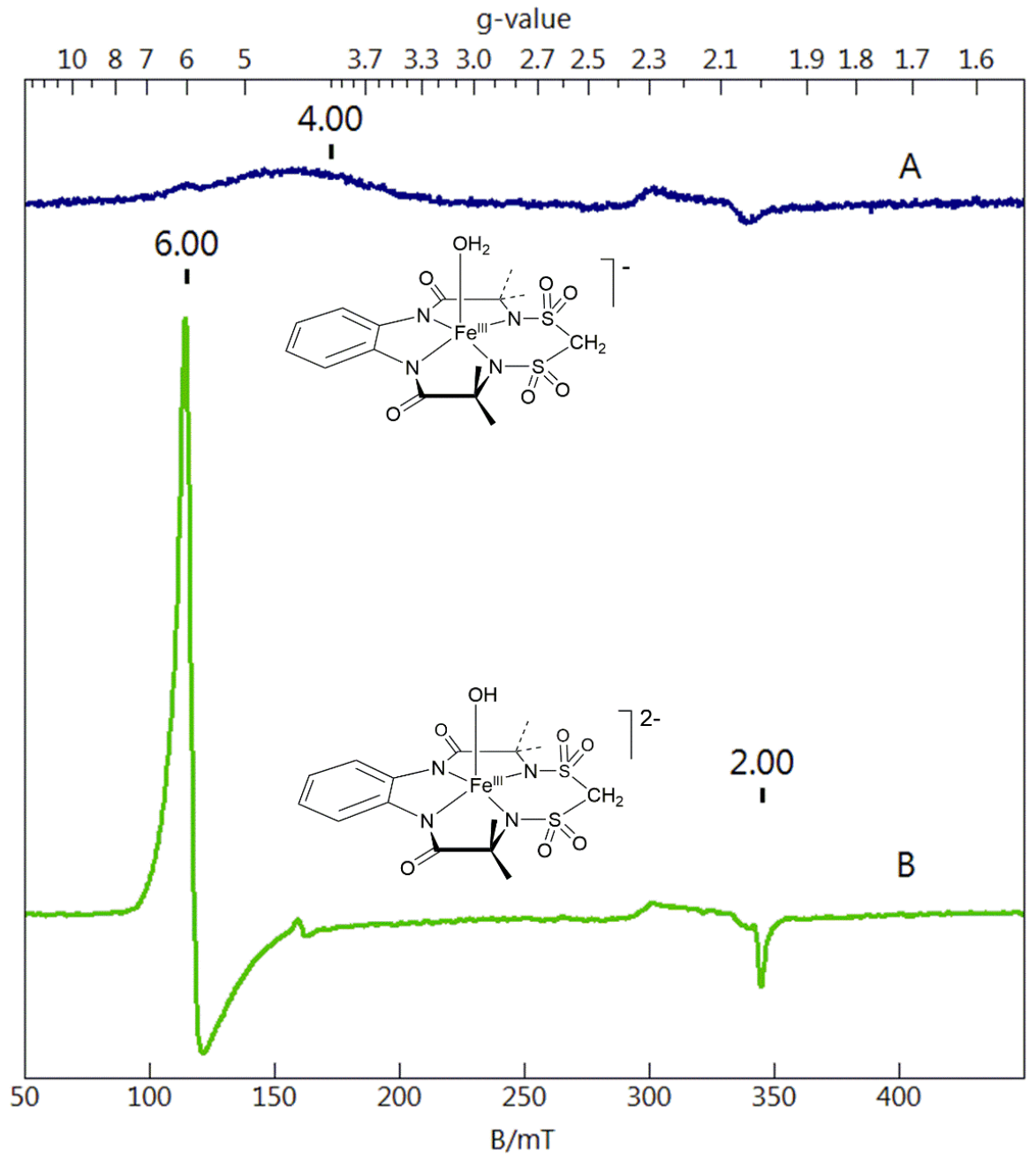

Figure S1. EPR spectra of $0.1 \mathrm{mM} 5 \mathrm{a}$ in phosphate buffer, $15 \%$ glycerol at $(\mathbf{A}) \mathrm{pH} 7.5$ and $(\mathbf{B}) \mathrm{pH}$ 11.5. Experimental conditions: temperature, $12.6 \mathrm{~K}$; microwaves, $0.2 \mathrm{~mW}$ at $9.645 \mathrm{GHz}$, modulation $1 \mathrm{mT}$ at $100 \mathrm{KHz}$. The signal with $\mathrm{g}$ $=2.3,2.05$ is a baseline impurity. 
Figure S2. Determination of $\mathrm{pK}_{\mathrm{a}}$ :

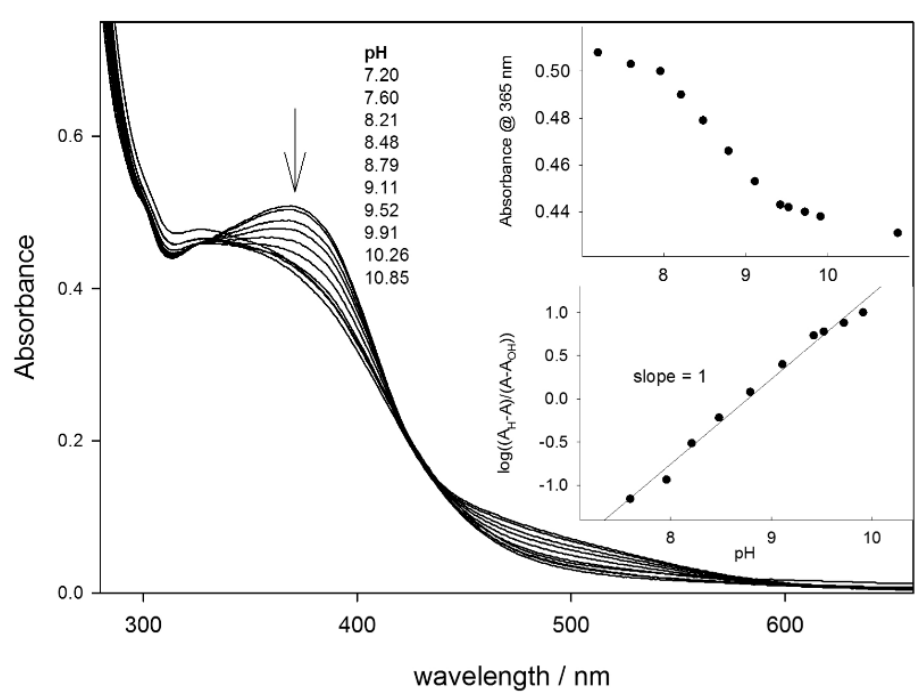

(Top) $\mathbf{5 b}\left(4.4 \times 10^{-5} \mathrm{M}\right)$ with varying $\mathrm{pH}$ in 0.01 $\mathrm{M}$ phosphate at $25{ }^{\circ} \mathrm{C}$. Insets: (Upper) Absorbance as a function of $\mathrm{pH}$ at $365 \mathrm{~nm}$; (Lower) Linearization of the data using the equation $\log \left(\left(\mathrm{A}_{\mathrm{H}}-\mathrm{A}\right) /\left(\mathrm{A}-\mathrm{A}_{\mathrm{OH}}\right)\right)=\mathrm{pH}-\mathrm{p} K_{\mathrm{a}}$, wherein $\mathrm{A}_{\mathrm{H}}, \mathrm{A}_{\mathrm{OH}}$, and $\mathrm{A}$ are absorbances at the most acidic, most basic, and intermediate $\mathrm{pHs}$, respectively. The resulting straight line with a slope of 1 results in a $\mathrm{x}$-intercept equal to $-\mathrm{p} K_{\mathrm{a}}$.
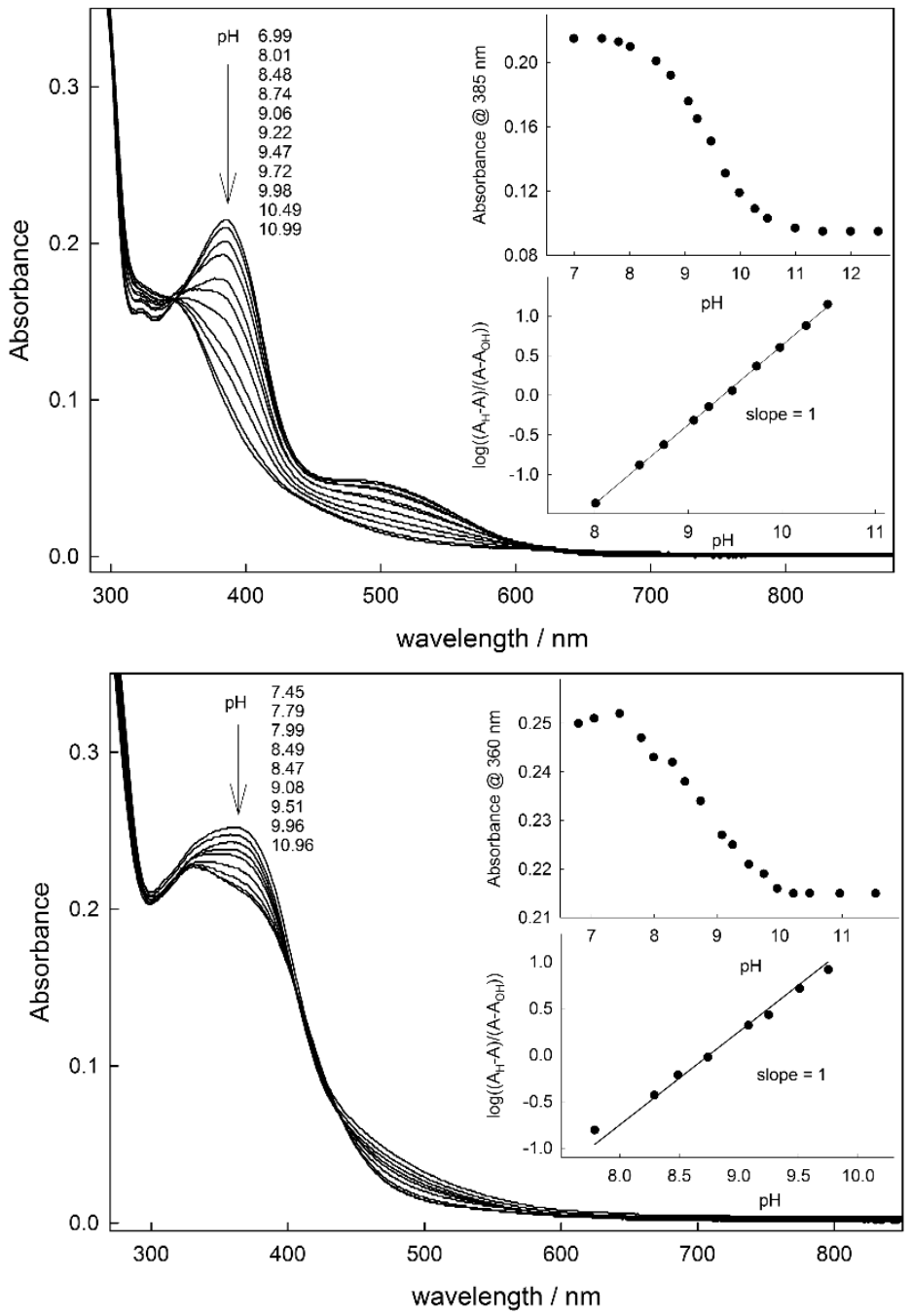

(Middle) $\mathbf{5 c}\left(5.1 \times 10^{-5} \mathrm{M}\right)$ with varying $\mathrm{pH}$ in 0.01 $\mathrm{M}$ phosphate at $25{ }^{\circ} \mathrm{C}$. Insets: (Upper) Absorbance as a function of $\mathrm{pH}$ at $385 \mathrm{~nm}$; (Lower) Linearization of the data using the equation $\log \left(\left(\mathrm{A}_{\mathrm{H}}-\mathrm{A}\right) /\left(\mathrm{A}-\mathrm{A}_{\mathrm{OH}}\right)\right)=\mathrm{pH}-\mathrm{p} K_{\mathrm{a}}$ wherein $\mathrm{A}_{\mathrm{H}}, \mathrm{A}_{\mathrm{OH}}$, and $\mathrm{A}$ are absorbances at the most acidic, most basic, and intermediate $\mathrm{pHs}$, respectively.

(Bottom) $\mathbf{5 d}\left(2.6 \times 10^{-5} \mathrm{M}\right)$ with varying $\mathrm{pH}$ in 0.01 $\mathrm{M}$ phosphate at $25^{\circ} \mathrm{C}$. Insets: (Upper) Absorbance as a function of $\mathrm{pH}$ at $360 \mathrm{~nm}$; (Lower) Linearization of the data using the equation $\log \left(\left(\mathrm{A}_{\mathrm{H}}-\mathrm{A}\right) /\left(\mathrm{A}-\mathrm{A}_{\mathrm{OH}}\right)\right)=\mathrm{pH}-\mathrm{p} K_{\mathrm{a}}$, wherein $\mathrm{A}_{\mathrm{H}}$, $\mathrm{A}_{\mathrm{OH}}$, and $\mathrm{A}$ are absorbances at the most acidic, most basic, and intermediate $\mathrm{pHs}$, respectively. 

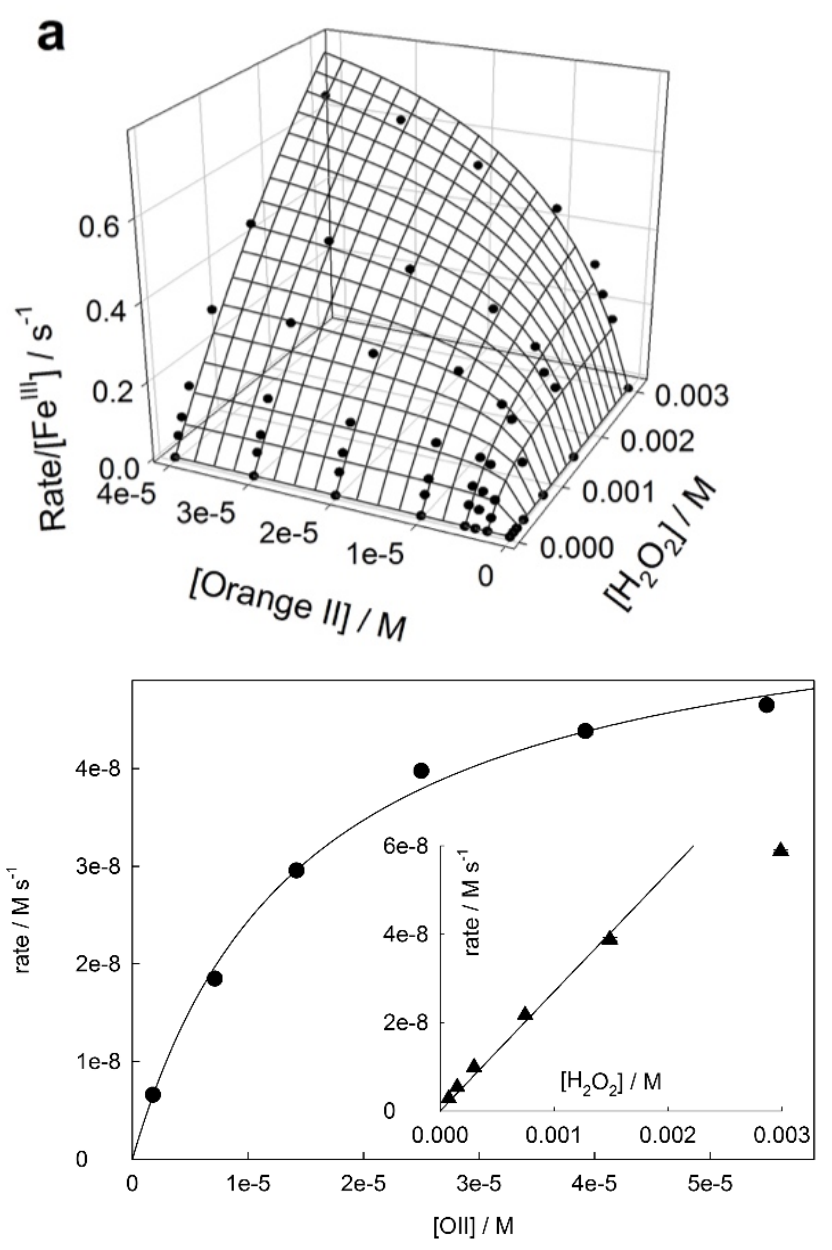
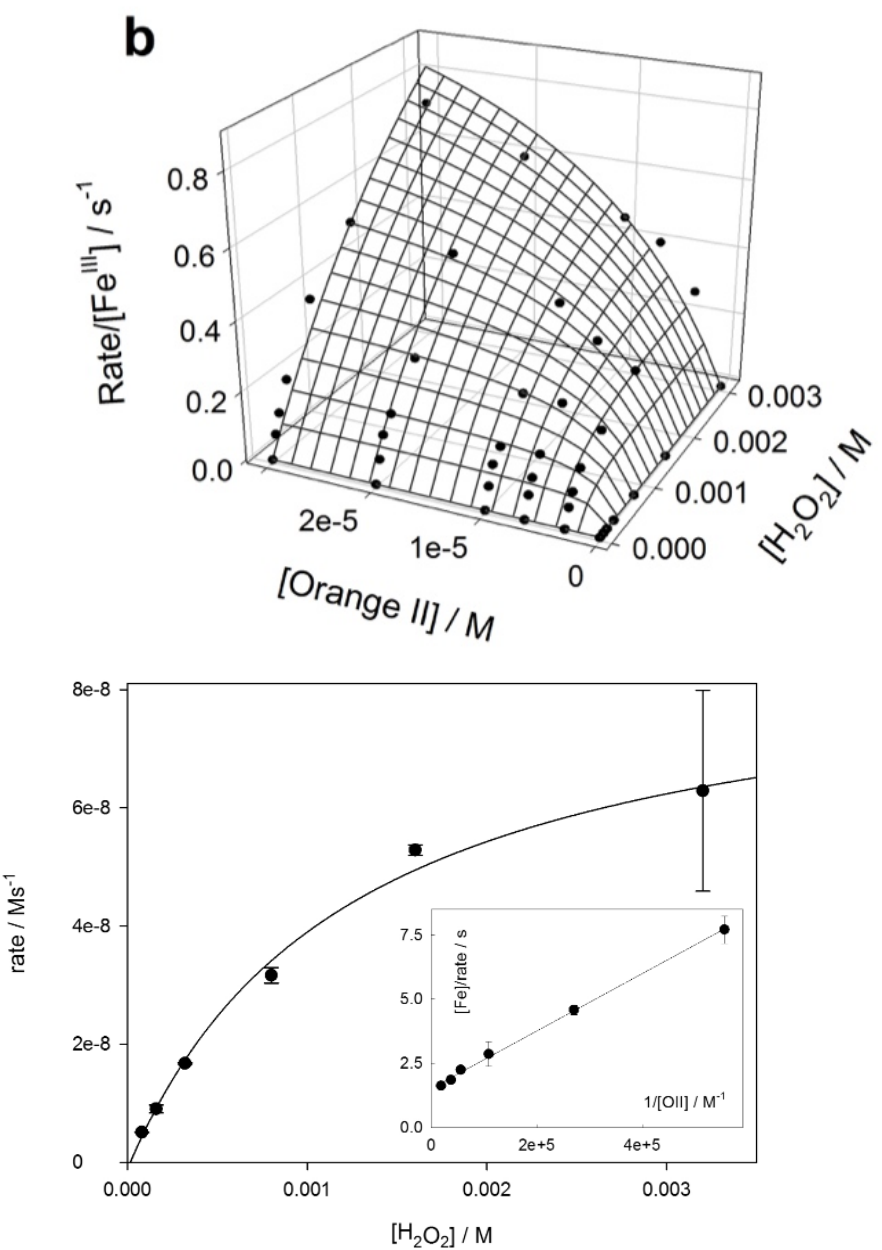

Figure S3. (Top) 3D mesh plot of the initial rate of Orange II bleaching by (Left, a) $2.6 \times 10^{-8} \mathrm{M} \mathrm{5a}$, (Right, b) $2.3 \times$ $10^{-8} \mathrm{M} \mathrm{5b}$, with $\mathrm{H}_{2} \mathrm{O}_{2}$ in $\mathrm{pH} 7\left(0.01 \mathrm{M}\right.$ phosphate) at $25^{\circ} \mathrm{C}$ as functions of $\mathrm{H}_{2} \mathrm{O}_{2}$ and Orange II concentrations used to generate the $k_{\mathrm{I}}$ and $k_{\mathrm{II}}$ values in Table 1 . The 3D mesh plot for $\mathbf{5 a}$ is also presented in Figure 3 of the paper and is reproduced here for clarity of comparison. (Bottom) Left: The initial rates of Orange II bleaching with $\mathbf{5 c}\left(1 \times 10^{-7}\right.$ $\mathrm{M})$ and $\mathrm{H} 2 \mathrm{O} 2\left(1.5 \times 10^{-3} \mathrm{M}\right)$ as a function of Orange II concentration with $0.01 \mathrm{M} \mathrm{pH} 7$ phosphate at $25^{\circ} \mathrm{C}$. Inset: Rates as a function of $\left[\mathrm{H}_{2} \mathrm{O}_{2}\right]$ with $\mathbf{5 c}\left(1 \times 10^{-7} \mathrm{M}\right)$, Orange II $\left(2.5 \times 10^{-5} \mathrm{M}\right)$ and $0.01 \mathrm{M} \mathrm{pH} 7$ phosphate at $25^{\circ} \mathrm{C}$. Right: The initial rates of Orange II bleaching with $\mathbf{5 d}\left(\right.$ left, $\left.1 \times 10^{-7} \mathrm{M}\right)$ and $\mathrm{H} 2 \mathrm{O} 2\left(1.6 \times 10^{-3} \mathrm{M}\right)$ as a function of Orange II concentration with $0.01 \mathrm{M} \mathrm{pH} 7$ phosphate at $25^{\circ} \mathrm{C}$. Inset: Rates as a function of $[\mathrm{H} 2 \mathrm{O} 2]$ with $\mathbf{5 d}\left(1 \times 10^{-7}\right.$ $\mathrm{M})$, Orange II $\left(2.7 \times 10^{-5} \mathrm{M}\right)$ and $0.01 \mathrm{M} \mathrm{pH} 7$ phosphate at $25^{\circ} \mathrm{C}$. 


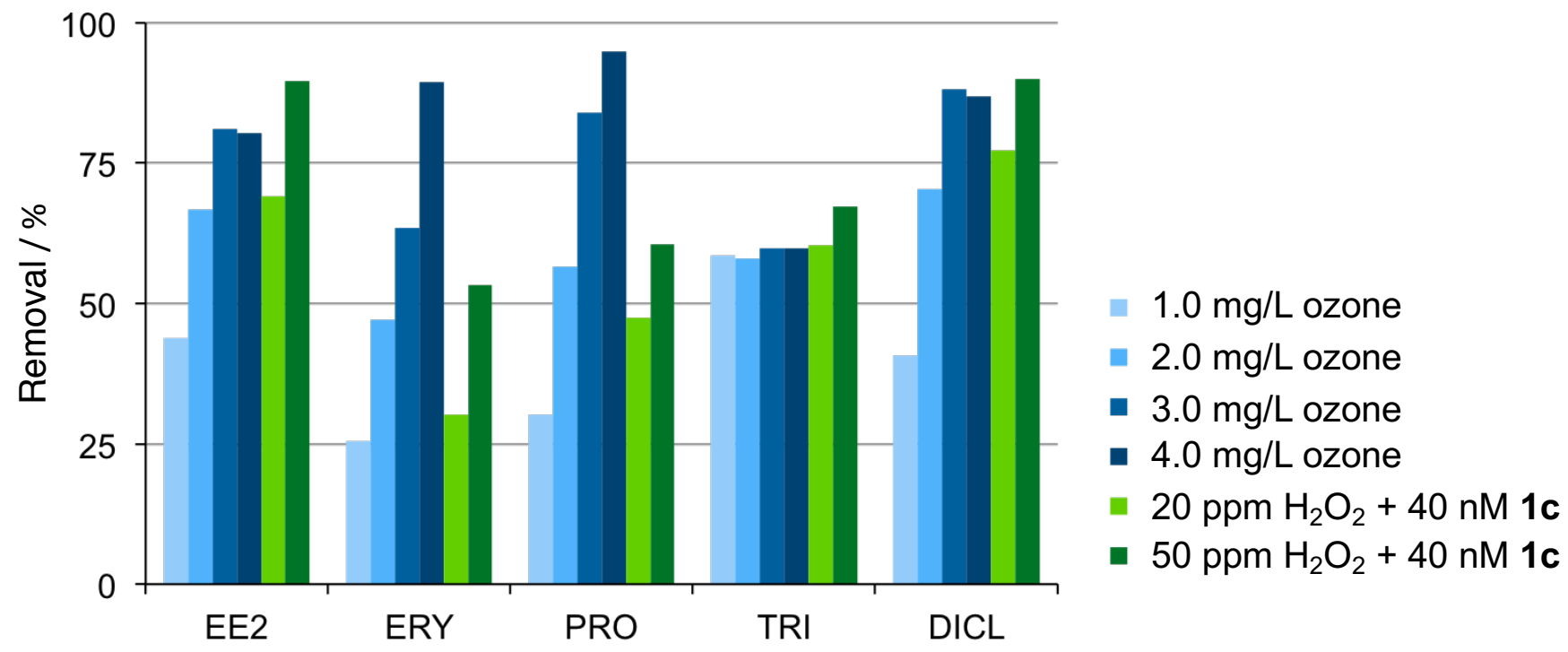

Figure S4. Comparison of percent removal of ethynylestradiol (EE2), erythromycin (ERY), propranolol (PRO), triclosan (TRI), and diclofenac (DICL) with ozone (blue) and TAML 1c with $\mathrm{H}_{2} \mathrm{O}_{2}$ (green) from London wastewater. $\left[\mathrm{H}_{2} \mathrm{O}_{2}\right]=20 \mathrm{mg} \mathrm{L}^{-1}$ with $\mathbf{1 c}(40 \mathrm{nM})$ is approximately equivalent to $2.0 \mathrm{mg} \mathrm{L}^{-1}$ ozone. $\left[\mathrm{H}_{2} \mathrm{O}_{2}\right]=50 \mathrm{mg} \mathrm{L}^{-}$ ${ }^{1}$ with $1 \mathbf{c}(40 \mathrm{nM})$ is approximately equivalent to $4.0 \mathrm{mg} \mathrm{L}^{-1}$ ozone. Graph adapted from data in reference 1. 

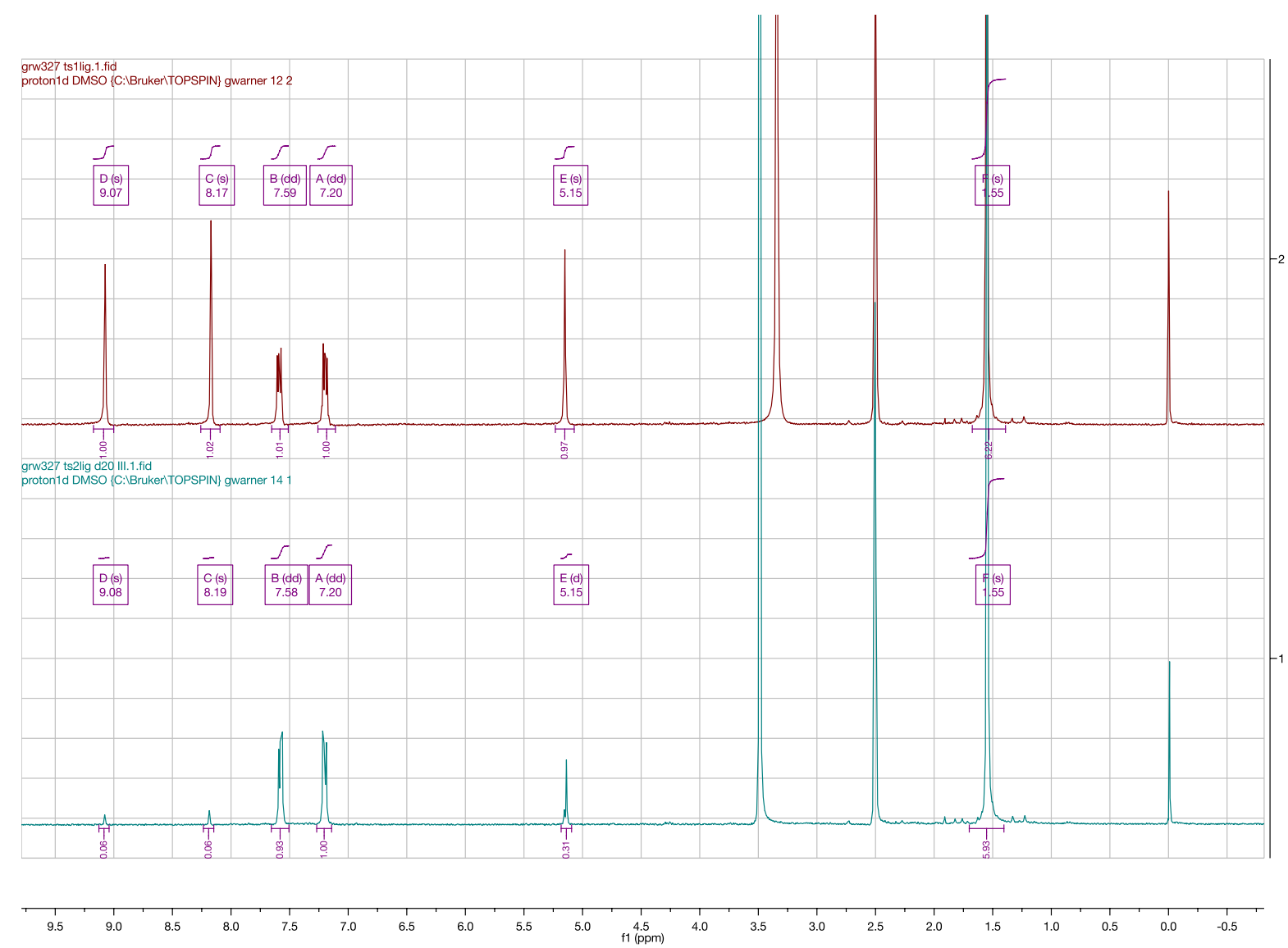

Figure S5: ${ }^{1} H$ NMR evidence for exchange of $R_{1}$ and $R_{2}$ protons with $D_{2} O$ in $E-5 a$, the unmetalated ligand of 5a. Top: ${ }^{1} \mathrm{H}$ NMR spectrum of unmetalated ligand (General compound E, Scheme S1) in DMSO- $d_{6}: \delta 9.07(\mathrm{~s}, 2 \mathrm{H}$, amide $\mathrm{N}-\underline{\mathrm{H}}) 8.17$ (s, $2 \mathrm{H}$, amide $\mathrm{N}-\underline{\mathrm{H}}$ ), 7.59 (dd, $2 \mathrm{H}$, aromatic $\mathrm{C}-\underline{\mathrm{H}}), 7.20$ (dd, $2 \mathrm{H}$, aromatic $\mathrm{C}-\underline{\mathrm{H}}), 5.15$ (d, $2 \mathrm{H}$, $\left.\left[\mathrm{RNHSO}_{2}\right]_{2} \mathrm{C}_{2}\right), 1.55\left(\mathrm{~s}, 12 \mathrm{H}, \underline{\mathrm{CH}}_{3}\right)$. Bottom: ${ }^{1} \mathrm{H}$ NMR spectrum of E-5a in DMSO- $d_{6}$ after $19 \mathrm{~h}$ at $25^{\circ} \mathrm{C}$ with one drop of $\mathrm{D}_{2} \mathrm{O}$ added. The amide protons at $9.07-8.17 \mathrm{ppm}$ and methylene protons at $5.15 \mathrm{ppm}$ exchange. The exchange was also confirmed by measuring the relative $\mathrm{m} / \mathrm{z}$ values in $\mathrm{H}_{2} \mathrm{O}$ and $\mathrm{D}_{2} \mathrm{O}$ by ESI-MS (neg mode); 5a: 470.2 and 472.2; 5b: 515.1 and 517.2; 1b: 479.3 and 479.2; respectively-spectra measured immediately after dissolving catalysts in water. 


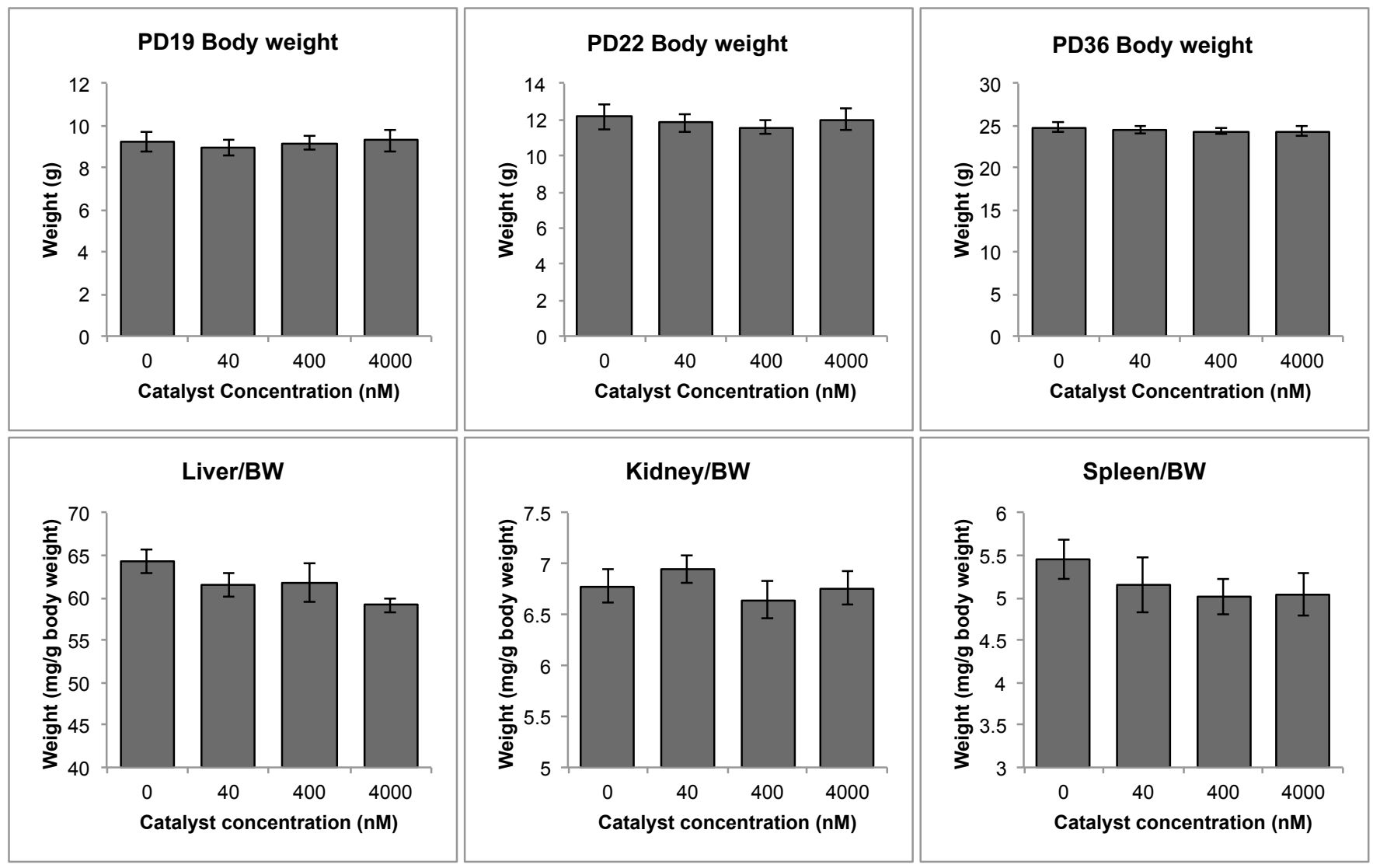

Figure S6. Body weight and liver and kidney weights in animals exposed to higher concentrations of 5a without EE2. The sample sizes for the $0,40,400$, and $4000 \mathrm{nM}$ treatments were 10,10,11, and 12, respectively. Body weights (upper row) are shown for postnatal day (PD) 19, prior to the start of catalyst exposure, PD 22, at the end of the treatment period, and PD36, two weeks after the end of the treatment period. Organ weights are presented as a relative to body weight (lower row). 


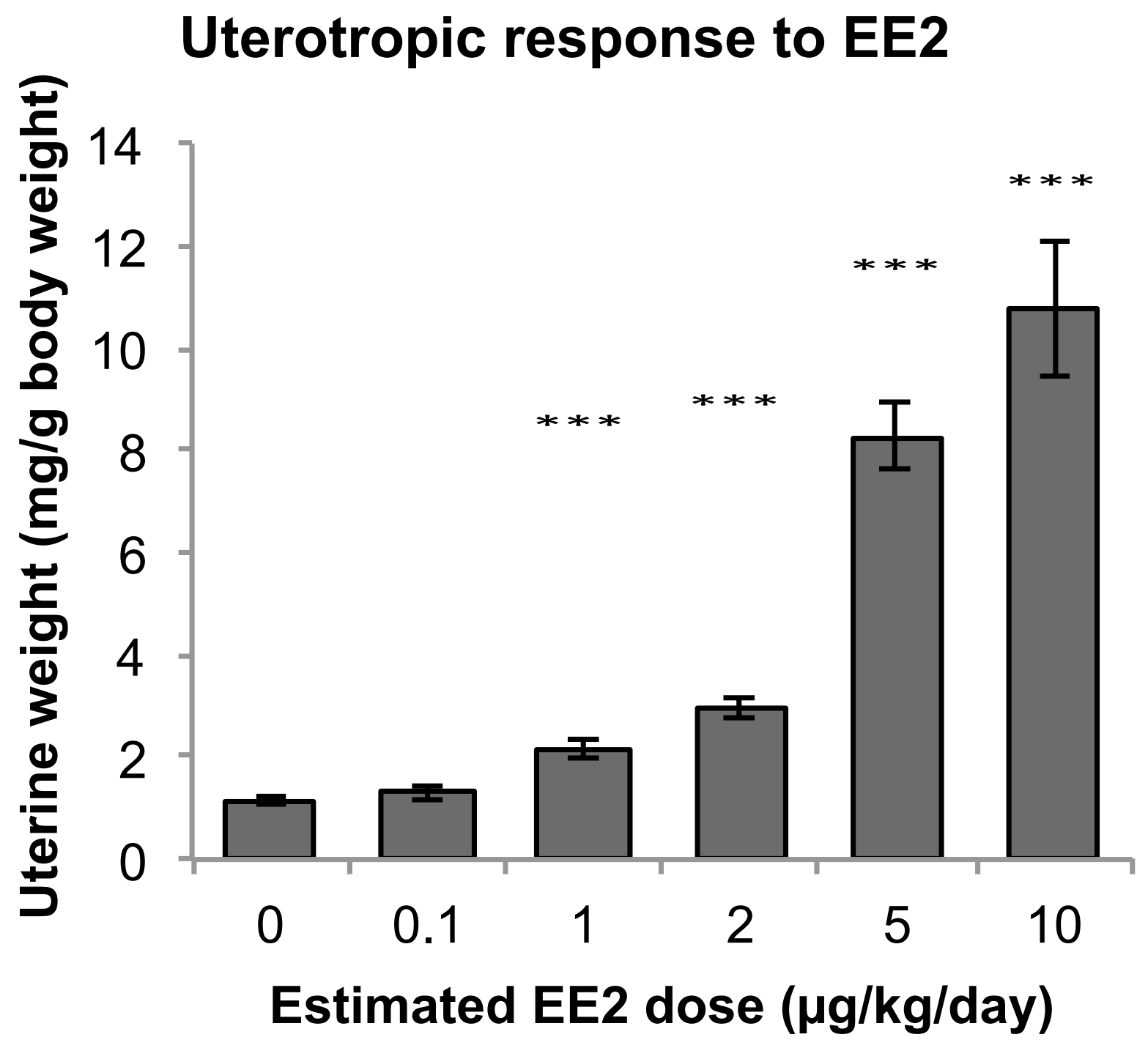

Figure S7. Uterine weight on postnatal day 22 after 3 days of EE2 treatment. The uterotropic response to EE2 administered in drinking water for three days. The sample sizes are 6, 4, 7, 3, 4, and 3 animals for $0,0.1,1,2,5$, and 10 $\mu \mathrm{g} / \mathrm{kg} /$ day doses, respectively. ${ }^{* * *} \mathrm{P}<0.0001$ vs. control $(0 \mu \mathrm{g} / \mathrm{kg} /$ day dose $)$. 


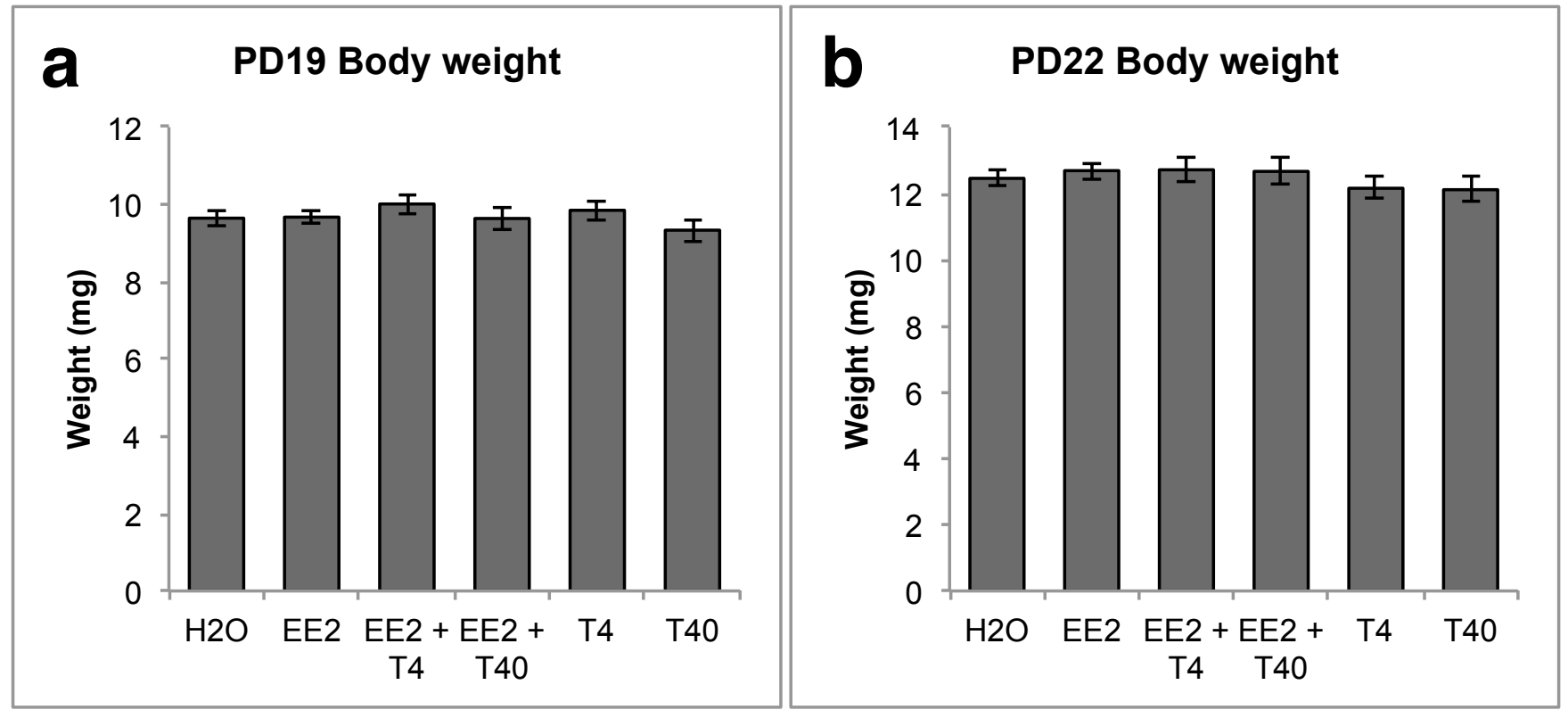

\section{Uterine weight/body weight}

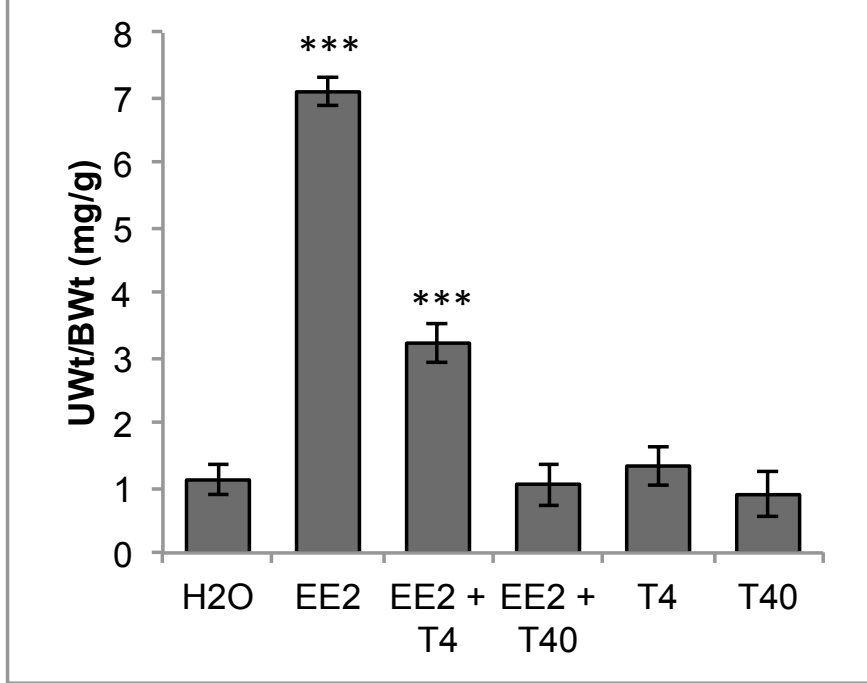

Figure S8. Body weight and uterine weight at the time of tissue collection on postnatal day 22. (a) Body weights on PD19, before exposure to the indicated solution and (b) on PD22, after exposure to the indicated solution for three days and (c) uterine weight corrected for body weight on PD22. The compositions of the exposure solutions were as follows; $\mathrm{H}_{2} \mathrm{O}$ : water control; EE2: 84 EE2; EE2+T4: 84 EE2 treated with $4 \mathrm{nM}$ 5a and $1 \mathrm{mM} \mathrm{H}_{2} \mathrm{O}_{2}$ for 1 hour and quenched with 0.5 ppm catalase; EE2 + T40: $84 \mathrm{EE} 2$ treated with $40 \mathrm{nM} 5 \mathbf{5 a}$ and $1 \mathrm{mM} \mathrm{H}_{2} \mathrm{O}_{2}$ for 3 hours and quenched with 0.5 ppm catalase; T4: $4 \mathrm{nM} 5 \mathbf{a}$; and T40: $40 \mathrm{nM}$ 5a. The sample sizes for the $\mathrm{H}_{2} \mathrm{O}, \mathrm{EE} 2$, EE2+T4, EE2+T40, T4 and $\mathrm{T} 40$ treatments were $20,20,11,12,10$ and 9 animals, respectively. ${ }^{* * *} \mathrm{P}<0.0001$ against the $\mathrm{H}_{2} \mathrm{O}$ data. 


\section{EXPERIMENTAL}

\section{Materials and Methods}

$\mathrm{Fe}^{\mathrm{III}}$-TAML complexes $\mathbf{1 a}, \mathbf{1 b}$, and $\mathbf{1} \mathbf{c}$ were prepared according to published methods ${ }^{2}$ or obtained from GreenOx Catalysts, Inc. Methods for preparation of $\mathrm{Fe}^{\mathrm{III}}$-NewTAML complexes $\mathbf{5}$ are given below. Methane disulfonyl dichloride was purchased from TCI or prepared as described elsewhere. ${ }^{3} \mathrm{H}_{2} \mathrm{O}_{2}(30 \% \mathrm{w} / \mathrm{w})$ was obtained from Fischer and its concentration was verified by UV/Vis spectroscopy using $\varepsilon=72.8 \mathrm{M}^{-1} \mathrm{~cm}^{-1}$ at $230 \mathrm{~nm}^{4}$ Orange II was purchased from Acros and recrystallized in aqueous ethanol. Catalase solutions (from Aspergillus niger, $2350 \mathrm{U} / \mathrm{mg}$ ) were prepared daily. All other reagents and solvents (at least ACS reagent grade) were obtained from commercial sources and used as received or purified according to standard procedures. ${ }^{5}$

\section{Instrumentation}

${ }^{1} \mathrm{H}$ and ${ }^{13} \mathrm{C}$ NMR data were collected on Bruker Avance III 300 and $500 \mathrm{MHz}$ instruments. Elemental analyses were performed by Midwest Microlabs, LLC. Mass spectrometry measurements were made on a Thermo-Fisher LCQ ESI/APCI Ion Trap. Solution $\mathrm{pH}$ was measured with a Corning $220 \mathrm{pH}$ meter. Spectrophotometric titration of $\mathbf{5 b}$ was performed using a double beam Shimadzu UV-1800 UV/Vis instrument with a CPS-240A 6-cell thermostated controller at $25^{\circ} \mathrm{C}$. UV-vis measurements were performed at $25^{\circ} \mathrm{C}$ on an Agilent 8453 spectrophotometer equipped with an automatic thermostated 8-cell positioner using capped acrylic cuvettes or on a TECAN Infinite M1000 Plate Spectrometer in 96-well polystyrene plates. High Performance Liquid Chromatography (HPLC) studies were performed with a Shimadzu LC system equipped with LC 20AB pump, SIL 20A autosampler, CTO 20A column oven, a RF 20A XS fluorescence detector, and a Kinetex (Phenomenex) EVO C18 100cA column $(4.6 \times 50$ mm, $5 \mu \mathrm{M})$.

\section{General Preparation of 5}

Compounds A-C (Scheme S1) were prepared as described elsewhere. ${ }^{2,6}$ Under Ar, a solution of $\mathbf{C}(1.5 \mathrm{mmol})$ and $\mathrm{Et}_{3} \mathrm{~N}(0.21 \mathrm{~mL})$ in dry THF $(40 \mathrm{~mL})$ and a solution of $\mathbf{D}(1.5 \mathrm{mmol})$ in dry THF $(40 \mathrm{~mL})$ were added dropwise with a syringe pump to THF $(250 \mathrm{~mL})$ at $0{ }^{\circ} \mathrm{C}$. The solution was allowed to warm overnight, then filtered. The solvent was partially removed, and the residue purified by column chromatography (silica gel, eluent 3:1:1 EtOAc/heptane/DCM) to yield ligand E. A solution of $n \mathrm{BuLi}(0.567 \mathrm{mmol}$ of $1.6 \mathrm{M}$ in hexane, $4.1 \mathrm{eq})$ was added at $0{ }^{\circ} \mathrm{C}$ to a soluiton of $\mathbf{E}(0.138 \mathrm{mmol})$ in $10 \mathrm{~mL}$ dry THF under Ar. The mixture stirred for $30 \mathrm{~min}$ before addition of solid anhydrous $\mathrm{FeCl}_{3}(0.166 \mathrm{mmol})$. The mixture was stirred at room temperature overnight. The solvent was removed, and the solids suspended in a minimum amount of 9:1 (v/v) water/methanol and filtered through a fine glass frit. The filtrate was partially reduced in vacuo and purified by flash chromatography on a C-18 silica gel column with 9:1 (v/v) water/methanol as the eluent. The lithium cation was replaced by tetramethylammonium using cationic exchange column (Amberlite IR-120) presaturated with $\left[\mathrm{NMe}_{4}\right]^{+}$. The red product was eluted in methanol and further purified by flash chromatography (C-18 silica gel, $\mathrm{CH}_{3} \mathrm{OH} / \mathrm{H}_{2} \mathrm{O}$, gradient elution). 


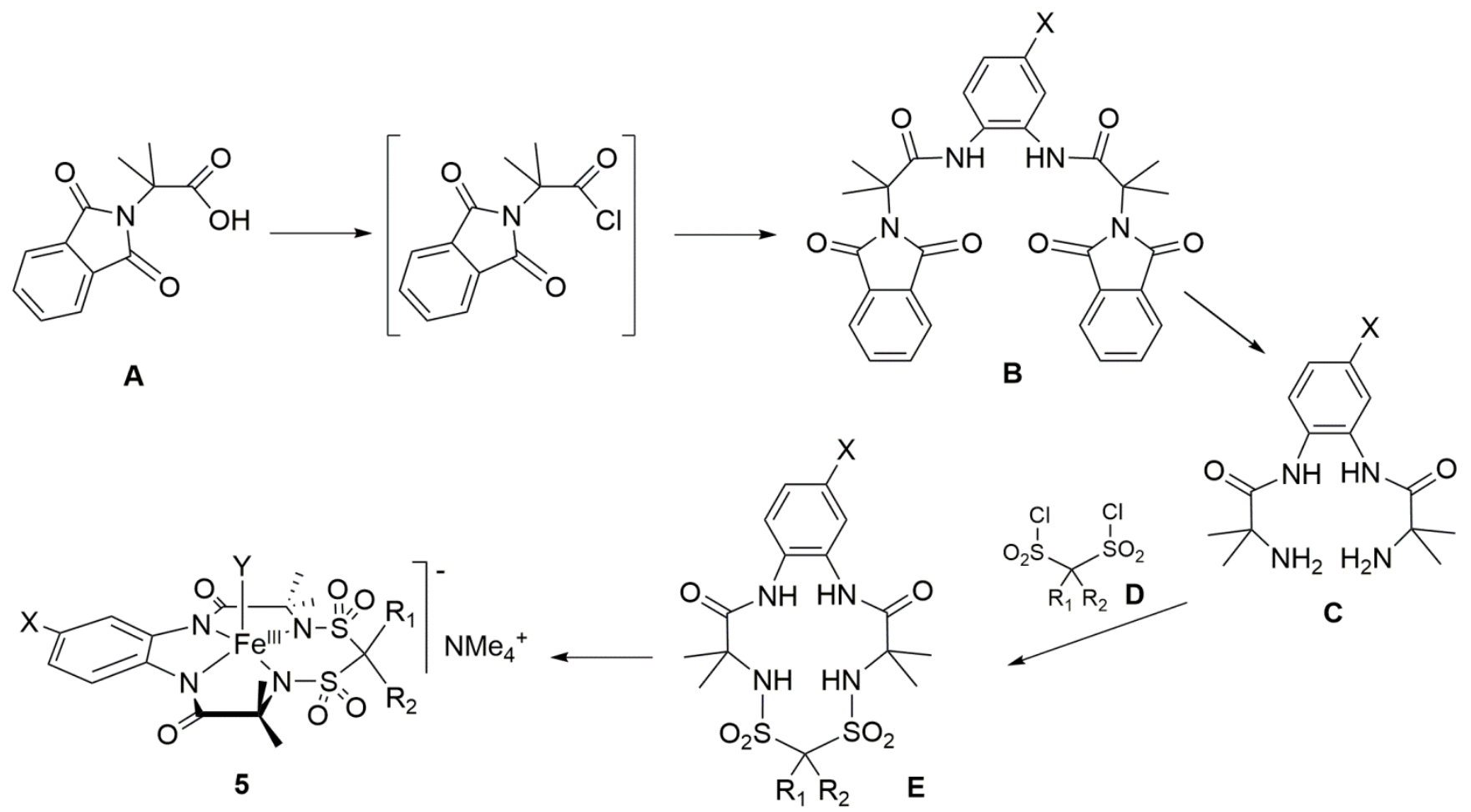

Scheme S1 General method for preparation of 5. Y is typically $\mathrm{H}_{2} \mathrm{O}$.

Preparation of $\mathbf{5 a}$ The general procedure for $\mathbf{5}$ with $\mathbf{C}(\mathrm{X}=\mathrm{H})$ and $\mathbf{D}\left(\mathrm{R}_{1}=\mathrm{R}_{1}=\mathrm{H}\right)$ gave $\mathbf{E}\left(\mathrm{X}=\mathrm{H}, \mathrm{R}_{1}=\mathrm{R}_{2}=\mathrm{H}\right)$ in $25 \%$ yield. ${ }^{1} \mathrm{H}$ NMR $\left(300 \mathrm{MHz}, \mathrm{DMSO}-\mathrm{d}_{6}\right) \delta 9.07(\mathrm{~s}, 2 \mathrm{H}), 8.16(\mathrm{~s}, 2 \mathrm{H}), 7.60(\mathrm{dd}, \mathrm{J}=6.0,3.6 \mathrm{~Hz}, 2 \mathrm{H}), 7.20(\mathrm{dd}, \mathrm{J}=$ $6.1,3.5 \mathrm{~Hz}, 2 \mathrm{H}), 5.15(\mathrm{~s}, 2 \mathrm{H}), 1.56(\mathrm{~s}, 12 \mathrm{H}) .{ }^{13} \mathrm{CNMR}\left(500 \mathrm{MHz}, \mathrm{DMSO}-d_{6}\right) \delta 172.86,130.61,125.81,125.59,71.35$, 61.00, 27.57. ESI-MS (neg mode): $\mathrm{m} / \mathrm{z} 417.2(\mathrm{M}-\mathrm{H}+, 100 \%)$. Metalation of E gave $\mathbf{5 a}$ at $23 \%$ yield. UV/Vis in $\mathrm{H}_{2} \mathrm{O}$ : $\lambda_{\max }=385 \mathrm{~nm}\left(\varepsilon=4710 \mathrm{~cm}^{-1} \mathrm{M}^{-1}\right)$; ESI-MS (neg mode): $\mathrm{m} / \mathrm{z}$ calcd: 470.0; found: 470.1 (M; 100\%); anal. calcd (\%) for $\mathrm{C}_{19} \mathrm{H}_{32} \mathrm{FeN}_{5} \mathrm{O}_{7} \mathrm{~S}_{2} \bullet 1 / 3 \mathrm{Et}_{2} \mathrm{O}$ : C 41.59, $\mathrm{H}$ 6.07, N 11.93; found: C 41.52, H 6.48, N 11.86.

Preparation of $\mathbf{5} \boldsymbol{b}$ The general procedure for $\mathbf{5}$ with $\mathbf{C}\left(\mathrm{X}=\mathrm{NO}_{2}\right)$ and $\mathbf{D}\left(\mathrm{R}_{1}=\mathrm{R}_{1}=\mathrm{H}\right)$ gave $\mathbf{E}\left(\mathrm{X}=\mathrm{NO}_{2}, \mathrm{R}_{1}=\mathrm{R}_{2}=\mathrm{H}\right)$ in $24 \%$ yield. ${ }^{1} \mathrm{H}$ NMR $\left(300 \mathrm{MHz}\right.$, DMSO- $\left.d_{6}\right) \delta 9.42(\mathrm{~s}, 1 \mathrm{H}), 9.31(\mathrm{~s}, 1 \mathrm{H}), 8.45(\mathrm{~d}, J=2.6 \mathrm{~Hz}, 1 \mathrm{H}), 8.28(\mathrm{~d}, J=11.8$ $\mathrm{Hz}, 2 \mathrm{H}), 8.14(\mathrm{dd}, J=9.1,2.7 \mathrm{~Hz}, 1 \mathrm{H}), 8.05(\mathrm{~d}, J=9.1 \mathrm{~Hz}, 1 \mathrm{H}), 5.19(\mathrm{~s}, 2 \mathrm{H}), 1.59(\mathrm{~s}, 12 \mathrm{H})$. ESI-MS (neg mode): $m / z$

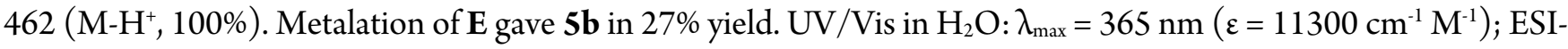
MS (neg mode): $\mathrm{m} / \mathrm{z}$ calcd: 514.99; found: 514.1 (M, 100\%); anal. calcd (\%) for $\mathrm{C}_{19} \mathrm{H}_{31} \mathrm{FeN}_{6} \mathrm{O}_{9} \mathrm{~S}_{2}$ : C 37.57, $\mathrm{H}$ 5.14, N 13.84; found: C 37.95, H 5.15, N 12.70.

Preparation of $\mathbf{5} \boldsymbol{c}$ Ethane-1,1-disulfonyl chloride was prepared as previously described. ${ }^{7}$ The general procedure for 4 with $\mathbf{C}(\mathrm{X}=\mathrm{H})$ and $\mathbf{D}\left(\mathrm{R}_{1}=\mathrm{H}, \mathrm{R}_{2}=\mathrm{CH}_{3}\right)$ gave $\mathbf{E}\left(\mathrm{X}=\mathrm{H}, \mathrm{R}_{1}=\mathrm{H}, \mathrm{R}_{2}=\mathrm{CH}_{3}\right)$ in $39 \%$ yield. ${ }^{1} \mathrm{H} \mathrm{NMR}(300 \mathrm{MHz}$, DMSO- $\left.d_{6}\right) \delta 9.20(\mathrm{~s}, 2 \mathrm{H}), 8.08(\mathrm{~s}, 2 \mathrm{H}), 7.69(\mathrm{~s}, 2 \mathrm{H}), 7.22(\mathrm{~s}, 2 \mathrm{H}), 5.10(\mathrm{q}, 1 \mathrm{H}), 1.68(\mathrm{~d}, 3 \mathrm{H}), 1.55(\mathrm{~d}, 12 \mathrm{H})$. ESI-MS (neg mode): $m / z 431.2\left(\mathrm{M}-\mathrm{H}^{+}, 100 \%\right)$. Metalation of $\mathbf{E}$ gave $\mathbf{5} \mathbf{c}$ in $79 \%$ yeild. $\mathrm{UV} / \mathrm{Vis}$ in $\mathrm{H}_{2} \mathrm{O}: \lambda_{\max }=385 \mathrm{~nm}(\varepsilon=4180$ $\mathrm{cm}^{-1} \mathrm{M}^{-1}$ ); ESI-MS (neg mode): $\mathrm{m} / \mathrm{z}$ calcd: 484.02; found: $484.2(\mathrm{M}$; 100\%); elemental anal. calcd (\%) for $\mathrm{C}_{20} \mathrm{H}_{34} \mathrm{FeN}_{5} \mathrm{O}_{7} \mathrm{~S}_{2}$ : C 41.67, H 5.94, N 12.15; found: C 40.12, H 6.04, N 11.34.

Preparation of $\mathbf{5} \boldsymbol{d}$ The general procedure for $\mathbf{5}$ with $\mathbf{C}\left(\mathrm{X}=\mathrm{NO}_{2}\right)$ and $\mathbf{D}\left(\mathrm{R}_{1}=\mathrm{H}, \mathrm{R}_{2}=\mathrm{CH}_{3}\right)$ gave $\mathbf{E}\left(\mathrm{X}=\mathrm{NO}_{2}, \mathrm{R}_{1}=\mathrm{H}\right.$, $\left.\mathrm{R}_{2}=\mathrm{CH}_{3}\right)$ in $48 \%$ yield. ${ }^{1} \mathrm{H}$ NMR $\left(300 \mathrm{MHz}\right.$, DMSO- $\left.d_{6}\right) \delta 9.62(\mathrm{~s}, 1 \mathrm{H}), 9.41(\mathrm{~s}, 1 \mathrm{H}), 8.50(\mathrm{~s}, 1 \mathrm{H}), 8.18(\mathrm{~m}, 4 \mathrm{H}), 5.13$

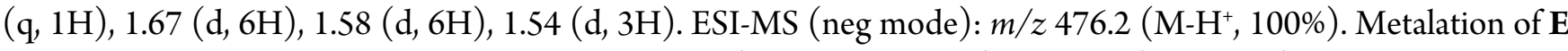
gave 5d in $44 \%$ yield. UV/Vis in $\mathrm{H}_{2} \mathrm{O}: \lambda_{\max }=360 \mathrm{~nm}\left(\varepsilon=9660 \mathrm{~cm}^{-1} \mathrm{M}^{-1}\right)$; ESI-MS (neg mode): $\mathrm{m} / \mathrm{z}$ calcd: 529.00; 
found: $529.2\left(\mathrm{M}\right.$, 100\%); elemental analysis calcd (\%) for $\mathrm{C}_{20} \mathrm{H}_{33} \mathrm{FeN}_{6} \mathrm{O}_{9} \mathrm{~S}_{2}$ : C 38.65, H 5.35, N 13.52; found: C 38.23, H 5.66, N 12.15 .

\section{X-ray Crystallography}

X-ray quality crystals of $\mathbf{5 a}$ formed upon slow diffusion of diethyl ether into a solution of the $\mathrm{NMe}_{5}^{+}$salt of $\mathbf{5 a}$ in acetonitrile. Crystallographic data for compound 5a were collected at 296(2) K using graphite-monochromated Mo Ka radiation $(0.71073 \AA)$ on a Bruker Smart Apex II CCD diffractometer. Data reduction included absorption corrections by the multiscan method using SADABS and refinement by full-matrix least squares using the SHELXTL 6.1 bundled software package. The $\mathrm{H}$ atoms were positioned geometrically (aromatic $\mathrm{C}-\mathrm{H} 0.93$, methylene $\mathrm{C}-\mathrm{H}$ 0.97, and methyl C-H 0.96) and treated as riding atoms during subsequent refinement, with $\mathrm{U}_{\text {iso }}(\mathrm{H})=1.2\left[\mathrm{U}_{\text {eq }}(\mathrm{C})\right]$ or $1.5\left[\mathrm{U}_{\text {eq }}(\right.$ methyl $\left.\mathrm{C})\right]$. The methyl groups were allowed to rotate about their local 3-fold axes. Crystallographic data have been deposited in the Cambridge Crystallographic Data Centre (CCDC 1521354) and can be obtained at https://www.ccdc.cam.ac.uk/structures-beta/.

\section{Measurement of $\mathrm{pK}_{\mathrm{a}}$}

The $\mathrm{p} K_{\mathrm{a}}$ of $\mathbf{5} \mathbf{b}$ was performed as described in detail previously. ${ }^{8}$

\section{Kinetics of Catalyzed Bleaching of Orange II}

The initial rates of consumption of Orange II in the presence of TAML and $\mathrm{H}_{2} \mathrm{O}_{2}$ were measured as described in detail elsewhere ${ }^{8,9}$ using a UV-Vis spectrometer or a plate reader. All reported values are the mean of at least three determinations. All calculations were made using Sigma Plot (versions 12.0 and 12.5).

UV-Vis Method Stock solutions of catalyst $\left(\right.$ ca. $\left.1 \times 10^{-6} \mathrm{M}\right)$, Orange II $\left(5 \times 10^{-4} \mathrm{M}\right)$, and $\mathrm{H}_{2} \mathrm{O}_{2}\left(4 \times 10^{-2} \mathrm{M}\right)$ were prepared in HPLC-grade water. Catalyst and Orange II were added to $1 \mathrm{~cm}$ acrylic cuvettes containing $0.01 \mathrm{M}$ phosphate buffer or Carmody buffer ${ }^{10}$ and the reactions were initiated by addition of peroxide. Values for $k_{\mathrm{I}}$ and $k_{\mathrm{II}}$ at $\mathrm{pH} 7$ given in Table 1 were determined from initial rates as functions of $\mathrm{H}_{2} \mathrm{O}_{2}$ and Orange II concentrations. For $\mathbf{5 a}$ $\left(2.6 \times 10^{-8} \mathrm{M}\right)$ and $\mathbf{5 b}\left(2.3 \times 10^{-8} \mathrm{M}\right)$, the data in $3 \mathrm{D}$ mesh plots were fit to the rate equation in Figure 1 , assuming $k_{\text {-I }}$ to be negligible ${ }^{9}$ (Figure S1). For $\mathbf{5 c}\left(9.8 \times 10^{-8} \mathrm{M}\right)$ and $\mathbf{5 d}\left(1.0 \times 10^{-7} \mathrm{M}\right), k_{\mathrm{I}}$ and $k_{\mathrm{II}}$ were determined from linear plots of $\mathrm{v}^{-1}$ vs. $\left[\mathrm{H}_{2} \mathrm{O}_{2}\right]^{-1}$ with $2.6 \times 10^{-5} \mathrm{M}$ Orange II or $\mathrm{v}^{-1}$ vs. [Orange II $]^{-1}$ with $1.6 \times 10^{-3} \mathrm{M} \mathrm{H}_{2} \mathrm{O}_{2}$, respectively (data not shown).

Plate Reader Method Initial rates as a function of $\left[\mathrm{H}_{2} \mathrm{O}_{2}\right]$ over $\mathrm{pH}$ 6-11.5 were measured using a plate reader. Hydrogen peroxide $\left(0.07-3.0 \times 10^{-3} \mathrm{M}\right)$ and Orange II $\left(2 \times 10^{-5} \mathrm{M}\right)$ were combined in 96-well plates with Carmody buffer and the reactions were initiated with catalyst. Values for $k_{\mathrm{I}}$ and $k_{\mathrm{II}}$ given in Figure 3 for $\mathbf{1 b}, \mathbf{1 c}, \mathbf{5 b}$, and $\mathbf{5 d}\left(0.5-2 \times 10^{-7} \mathrm{M}\right)$ were determined as above from linear plots of $\mathrm{v}^{-1} \mathrm{vs}$. $\left[\mathrm{H}_{2} \mathrm{O}_{2}\right]^{-1}$.

Incomplete Bleaching Measurements to determine $k_{\mathrm{i}}$ were performed on the UV-Vis as described in detail previously ${ }^{11}$ with minimal catalyst concentrations $\left(0.1-1 \times 10^{-7} \mathrm{M}\right)$ and Orange II $\left(4.5 \times 10^{-5} \mathrm{M}\right), \mathrm{H}_{2} \mathrm{O}_{2}\left(1.6 \times 10^{-3} \mathrm{M}\right)$, and phosphate $(0.01 \mathrm{M})$ or Carmody buffer.

\section{Propranolol Degradation by Catalyst $/ \mathrm{H}_{2} \mathrm{O}_{2}$}

Stock solutions of catalyst $\left(1 \times 10^{-5} \mathrm{M}\right)$, propranolol $\left(4 \times 10^{-6} \mathrm{M}\right)$, and $\mathrm{H}_{2} \mathrm{O}_{2}(1 \mathrm{M})$ were prepared in HPLC grade water. Appropriate volumes of phosphate buffer $(0.01 \mathrm{M})$, propranolol, and catalyst stock solutions were combined and equilibrated to $25 \pm 2^{\circ} \mathrm{C}$ in a water bath. The reaction was initiated by the addition of an appropriate volume of 
the peroxide stock solution to give a final volume of $10 \mathrm{~mL}$ with $1.0 \times 10^{-7} \mathrm{M}$ catalyst, $3.3 \times 10^{-4} \mathrm{M} \mathrm{H}_{2} \mathrm{O}_{2}$, and $5.8 \times 10^{-}$

${ }^{8} \mathrm{M}$ propranolol. At pre-determined time intervals, aliquots were withdrawn, and the concentration of propranolol was determined using HPLC. The LC method consisted of $1 \mathrm{~mL} / \mathrm{min}$ flow rate, $35 \%$ methanol $/ 65 \% \mathrm{pH} 30.01 \mathrm{M}$ phosphate buffer, $40^{\circ} \mathrm{C}$ column temperature, and fluorescence detection by excitation at $230 \mathrm{~nm}$ and monitoring of the $340 \mathrm{~nm}$ emission wavelength. For the measurement of parts per billion concentrations of propranolol, the sensitivity was set to medium with $4 \mathrm{X}$ gain for the signal and the sample injection volume for the analysis was $100 \mu \mathrm{L}$. All propranolol peaks were integrated automatically, and the data was analyzed using Lab solutions software. All reported values are the mean of three determinations.

\section{SUPPORTING INFORMATION REFERENCES}

(1) Churchley, J.; Collins, T.; Jobling, S. Catalytic Oxidation of Pharmaceutical Compounds in Wastewater Effluents. UKWIR Report 2013, 13/WW/17/14..

(2) $\mathrm{CMU}$ Institute for Green Science, https://www.cmu.edu/igs/. Patents at https://www.cmu.edu/igs/pub/patents.html.

(3) Fild, M.; Rieck, H. P. Production of alpha-Substituted Methanesulfonic Acid Chlorides. Chem. Ztg. 1976, 100, 391-392..

(4) George, P. The Chemical Nature of the Second Hydrogen Peroxide Compound Formed by Cytochrome c Peroxidase and Horseradish Peroxidase. Biochem. J. 1953, 54, 267-276..

(5) Armarego, W. L. F.; Chai, C. L. L. Purification of Laboratory Chemicals. 5th ed.; Elsevier Science: USA, 2003.

(6) Ghosh, A.; Ramidi, P.; Pulla, S.; Sullivan, S. Z.; Collom, S. L.; Gartia, Y.; Munshi, P.; Biris, A. S.; Noll, B. C.; Berry, B. C. Cycloaddition of $\mathrm{CO}_{2}$ to Epoxides Using a Highly Active Co(III) Complex of Tetraamidomacrocyclic Ligand. Catal. Lett. 2010, 137, 1-7.

(7) Murakami, S.; Onozuka, T.; Fujita, K. Preparation of Methylenedisulfonic Acid Compounds and Cyclic MethylenediSulfonate Compounds. JP 2014062076A.; 2014, 19 pp.

(8) Warner, G.; Mills, M.; Enslin, C.; Pattanayak, S.; Panda, C.; Sen Gupta, S.; Ryabov, A. D.; Collins, T. J. Reactivity of $N$-Tailed ('Biuret') TAMLs in Water: Kinetics of the Catalyzed Oxidation of Orange II by $\mathrm{H}_{2} \mathrm{O}_{2}$. Synthesis and X-Ray Characterization of an $N$-Phenyl Biuret TAML. Chem. Eur. J. 2015, 21, 6226-6233.

(9) Chahbane, N.; Popescu, D.-L.; Mitchell, D. A.; Chanda, A.; Lenoir, D.; Ryabov, A. D.; Schramm, K.-W.; Collins, T. J. Fe ${ }^{\mathrm{III}}$-TAML-Catalyzed Green Oxidative Degradation of the Azo Dye Orange II by $\mathrm{H}_{2} \mathrm{O}_{2}$ and Organic Peroxides: Products, Toxicity, Kinetics, and Mechanisms. Green Chem. 2007, 9, 49-57.

(10) Carmody, W. R. An Easily Prepared Wide-Range Buffer Series. J. Chem. Educ. 1961, 38, 559-60.

(11) DeNardo, M. A.; Mills, M. R.; Ryabov, A. D.; Collins, T. J. Unifying Evaluation of the Technical Performances of Iron-Tetra-Amido Macrocyclic Ligand Oxidation Catalysts. J. Am. Chem. Soc. 2016, 138, 2933-2936.

(12) Becke, A. D. Density-Functional Thermochemistry. III. The Role of Exact Exchange. J. Chem. 
Phys. 1993, 98, 5648-5652.

(13) Becke, A. D. Density-Functional Exchange-Energy Approximation with Correct Asymptotic Behavior. Phys. Rev. A: Gen. Phys. 1988, 38, 3098-3100.

(14) Lee, C.; Yang, W.; Parr, R. G. Development of the Colle-Salvetti Correlation-Energy Formula into a Functional of the Electron Density. Phys. Rev. B: Condens. Matter 1988, 37, 785-789.

(15) Frisch, M. J.; Trucks, G. W.; Schlegel, H. B.; Scuseria, G. E.; Robb, M. A.; Cheeseman, J. R.; Scalmani, G.; Barone, V.; Mennucci, B.; Petersson, G. A.; Nakatsuji, H.; Caricato, M.; Li, X.; Hratchian, H. P.; Izmaylov, A. F.; Bloino, J.; Zheng, G.; Sonnenberg, J. L.; Hada, M.; Ehara, M.; Toyota, K.; Fukuda, R.; Hasegawa, J.; Ishida, M.; Nakajima, T.; Honda, Y.; Kitao, O.; Nakai, H.; Vreven, T.; Montgomery, J. A.; Peralta, J. E.; Ogliaro, F.; Bearpark, M.; Heyd, J. J.; Brothers, E.; Kudin, K. N.; Staroverov, V. N.; Kobayashi, R.; Normand, J.; Raghavachari, K.; Rendell, A.; Burant, J. C.; Iyengar, S. S.; Tomasi, J.; Cossi, M.; Rega, N.; Millam, J. M.; Klene, M.; Knox, J. E.; Cross, J. B.; Bakken, V.; Adamo, C.; Jaramillo, J.; Gomperts, R.; Stratmann, R. E.; Yazyev, O.; Austin, A. J.; Cammi, R.; Pomelli, C.; Ochterski, J. W.; Martin, R. L.; Morokuma, K.; Zakrzewski, V. G.; Voth, G. A.; Salvador, P.; Dannenberg, J. J.; Dapprich, S.; Daniels, A. D.; Farkas; Foresman, J. B.; Ortiz, J. V.; Cioslowski, J.; Fox, D. J. In Gaussian 09, Revision D.01, Gaussian, Inc., Wallingford CT, 2009.

(16) Marenich, A. V.; Cramer, C. J.; Truhlar, D. G. Universal Solvation Model Based on Solute Electron Density and on a Continuum Model of the Solvent Defined by the Bulk Dielectric Constant and Atomic Surface Tensions. J. Phys. Chem. B 2009, 113, 6378-6396.

(17) Petasis, D. T.; Hendrich, M. P. Quantitative Interpretation of Multifrequency Multimode EPR Spectra of Metal Containing Proteins, Enzymes, and Biomimetic Complexes Methods Enzym. 2015, 563, 171-208. 